\title{
HISTAMINE AND 5-HYDROXYTRYPTAMINE IN THE BLOOD OF INFANTS AND CHILDREN
}

\author{
By ROSS G. MITCHELL AND ROSEMARY CASS * \\ (From the Departments of Child Health and of Pharmacology and Therapeutics, University of \\ St. Andrews, Dundee, Scotland)
}

(Submitted for publication October 6, 1958; accepted November 6, 1958)

Evidence from a number of sources indicates that the amount of histamine in the blood of healthy adult human beings is usually within the range 0.01 to $0.08 \mu \mathrm{g}$. per $\mathrm{ml}$. (1) and that nearly all of it is in the basophil and eosinophil leukocytes $(2,3)$. The little information available about the blood of children suggests that the total content of histamine is similar to that of adult blood. Thus, Maas, Fehmers and Strengers (4) estimated the histamine content of the blood of 51 normal children. Several determinations were made on each child and the average values recorded; all except two fell within the adult range, although individual values were more variable. Unfortunately, these workers did not relate the values obtained to the numbers of basophils and eosinophils in the blood, nor did they determine whether any of the histamine was in the plasma. Little if any histamine is normally present in the plasma of healthy adults (5), but the report by Pettay (6) that the plasma of umbilical cord blood contained 0.06 to $0.20 \mu \mathrm{g}$. of histamine per ml. suggested that the blood in early life might differ in this respect from adult blood. The present investigation was undertaken to determine the amount of histamine in the blood at birth and in childhood and its distribution among the various elements of the blood.

There is usually a numerical relationship between the basophils and eosinophils in the blood $(7,8)$, although not a close one, and in quantitative studies it has proved difficult to determine the distribution of histamine between the two types of cell (3). In an attempt to shed further light on this problem, a study was made of children who had abnormally large numbers of these cells in the circulation or in whose blood there was a wide dissociation between the numbers of basophils and eosinophils.

There have been few reports on the 5-hydroxy-

* Present address: Laboratory of Chemical Pharmacology, National Heart Institute, Bethesda, Md. tryptamine (HT) content of the blood in infancy and childhood. According to Erspamer (9), the serum of newborn infants contains only a small quantity of $\mathrm{HT}(0.07 \mu \mathrm{g}$. per ml.). In contrast, higher values have been recorded in older children by Pare, Sandler and Stacey (10), who found the mean value in the serum of 15 children awaiting tonsillectomy to be $0.124 \mu \mathrm{g}$. per ml. However, since $\mathrm{HT}$ is contained almost solely in the platelets, values obtained from serum are likely to be very variable, depending on the extent to which $\mathrm{HT}$ has been lost from the platelets during clotting. In the present study, HT was estimated in the platelets of the infants and children, and the plasma was also examined to detect any $\mathrm{HT}$ which might have escaped during collection or separation of the blood.

\section{MATERIAL AND METHODS}

Blood from 11 mature newborn infants was obtained from the umbilical vein before division of the umbilical cord, using a $30 \mathrm{ml}$. siliconed glass syringe. Five ml. of the blood was immediately added to $1 \mathrm{ml}$. of 3.8 per cent sodium citrate in a siliconed tube for determination of HT. Six ml. was added to $0.1 \mathrm{ml} .3 .8$ per cent sodium citrate in a siliconed tube and immediately centrifuged for five minutes, after which a measured quantity of the plasma was added by siliconed pipette to $5 \mathrm{ml}$. of 10 per cent trichloracetic acid for determination of plasma histamine. While this sample was being centrifuged, counting pipettes were filled directly from the blood in the syringe for enumeration of basophils, eosinophils and platelets. Next, two samples of $5 \mathrm{ml}$. blood were taken in siliconed pipettes and each added to $10 \mathrm{ml}$. of 10 per cent trichloracetic acid for duplicate determinations of total blood histamine. The remaining blood was used for the determination of the potassium content of the plasma. The whole procedure of partitioning the blood between the various containers was accomplished rapidly in the labor room and was completed within a few minutes of birth.

Blood from 16 children aged between one and 12 years was drawn from the anterior cubital vein, the routine being the same as for umbilical venous blood. Blood from 10 infants under one year old was drawn from the in- 
ternal jugular vein, using a $10 \mathrm{ml}$. siliconed syringe since only about $6 \mathrm{ml}$. was required for $\mathrm{HT}$ determination and a platelet count. The children and infants were in hospital either for correction of an anatomical abnormality, such as inguinal hernia, or for investigation of some minor complaint for which no cause was found. None had a history of allergic conditions and all could reasonably be regarded as healthy children. In each case, venous blood was required for routine diagnostic purposes and blood for the investigation was taken at the same time to avoid an unnecessary venipuncture. Venous blood from six healthy adults was also examined to obtain an indication of the normal adult value for HT by our method.

The capacity of the blood platelets to take up HT was assessed by incubating a suspension of platelets for one hour at $37^{\circ} \mathrm{C}$. in the presence of an excess of HT, using a suspension of the same platelets incubated with saline alone as the control. This test was carried out on two samples of umbilical venous blood and on two samples of venous blood from healthy adults.

Four children with eosinophilia were examined, eosinophilia being defined as more than 1,000 eosinophils per cu. mm. of blood. In two, the eosinophilia was associated with normal numbers of basophils, while in the other two there was also a basophilia. The first child (Case 1) was a boy of four years who had periorbital edema of six weeks' duration. Investigation revealed no cause for the eosinophilia and he had no other symptoms. The swelling gradually subsided but the eosinophil count remained high, though temporarily reduced by cortisone; one year later, the eosinophilia was still present.

The second child (Case 2) was a boy of five years, who had periorbital edema of three days' duration. He had a history of mild asthma and edema whenever he came in contact with cats. The swelling and eosinophilia subsided within a few days without specific treatment.

The third child with eosinophilia (Case 3) was a girl of six and one-half years with celiac disease, which responded to a diet without gluten. On admission, her blood contained large numbers of basophils and eosinophils, which increased still further during the next two months in spite of clinical improvement. A single dose of $200 \mathrm{mg}$. of cortisone only caused a small reduction in the numbers of basophils and eosinophils, and when she finally went home she still had a gross basophilia and eosinophilia. Her eight year old brother (Case 4) was also found to have a basophilia and eosinophilia. Full investigation of these two children, their parents, and their environment revealed no cause for the abnormal blood counts.

No case of basophilia without eosinophilia was encountered, but observations were made on one boy aged six years (Case 5), who had a low eosinophil count with a basophil count at the upper limit of normal. He had acute rheumatism of two weeks' duration, with signs of cardiac failure, the expected eosinopenia, but an unexpectedly high basophil count (110 per cu. mm.). In spite of treatment with sodium salicylate and cortisone, which resulted in a reduction in the number of basophils (to 25 per cu. mm.), there was no clinical improvement and he died five days after admission.

One further child, a girl aged 11 years with acute rheumatic carditis (Case 6), was studied throughout the course of her illness to determine whether the level of blood histamine bore the same relationship to the basophil and eosinophil counts as in health.

Histamine in blood was determined by Code's modification (11) of Barsoum and Gaddum's method (12). Histamine was extracted from plasma by the same method, using smaller quantities. Thus 2.5 to $3 \mathrm{ml}$. of plasma was added to $5 \mathrm{ml}$. of 10 per cent trichloracetic acid, filtered and washed with $5 \mathrm{ml}$. of 5 per cent trichloracetic acid. Three ml. of concentrated hydrochloric acid was added and the procedure continued as for whole blood. In seven recovery experiments, in which 0.05 or $0.1 \mu \mathrm{g}$. of histamine was added to each $\mathrm{ml}$. of plasma, the mean percentage of the added histamine recovered was $85 \pm 12$.

For assay, which was carried out on a strip of guinea pig ileum suspended in atropinized Tyrode's solution, the dried residue was taken up to its original volume in Tyrode's solution diluted 3: 1 with distilled water, and neutralized with sodium hydroxide. Each sample was assayed by comparison with a standard solution of histamine acid phosphate, and evidence that the activity measured was due to histamine was obtained by frequent tests with mepyramine maleate (13). All values for blood histamine in this paper are mean values of duplicate samples and are expressed in terms of the free base.

The plasma potassium content of each sample of blood was estimated by flame photometry, since abnormally high levels of potassium might have interfered with the assay of histamine. In every instance the potassium was within the normal range. Basophils and eosinophils were counted by the method of Moore and James (14), with the modifications previously described $(15,16)$.

For the determination of HT in platelets and plasma, $5 \mathrm{ml}$. of blood with $1 \mathrm{ml}$. of 3.8 per cent sodium citrate was centrifuged at $1,000 \mathrm{rpm}$ on a M.S.E. Major centrifuge $(250 \mathrm{G})$ for 10 minutes. The supernatant, platelet-rich plasma was pipetted off and centrifuged at 3,500 rpm $(3,000 \mathrm{G})$ for 20 minutes. The plasma was decanted off the sheet or "button" of platelets, and each was extracted with acetone, using $5 \mathrm{ml}$. for the platelets and four volumes for the plasma. The extracts were allowed to stand at room temperature for one hour and then centrifuged, and each supernatant decanted into a round-bottomed Quickfit flask. The residues were washed with 95 per cent acetone for 30 minutes and centrifuged, each supernatant being added to the contents of the corresponding Quickfit flask. Finally, the extracts were evaporated to dryness in vacuo at $37^{\circ} \mathrm{C}$. external temperature, and stored at $-17^{\circ} \mathrm{C}$. until they could be assayed, which was nearly always accomplished within two days. All glassware used in the extraction before the addition of acetone was treated with silicone.

The assay was performed on the atropinized, estrous 
BLOOD HISTAMINE AND 5-HYDROXYTRYPTAMINE IN CHILDREN

TABLE I

Histamine and 5-hydroxytryptamine in the blood of healthy newborn infants *

\begin{tabular}{|c|c|c|c|c|c|c|c|c|c|}
\hline \multirow[b]{2}{*}{ No. } & \multirow[b]{2}{*}{ Sex } & \multirow[b]{2}{*}{$\begin{array}{l}\text { Basophils/ } \\
\text { cu. mm. }\end{array}$} & \multirow[b]{2}{*}{$\begin{array}{l}\text { Eosinophils/ } \\
\text { cu. mm. }\end{array}$} & \multicolumn{2}{|c|}{ Histamine } & \multirow[b]{2}{*}{ Platelets } & \multicolumn{3}{|c|}{ 5-Hydroxytryptamine } \\
\hline & & & & Blood & Plasma & & $\begin{array}{l}\text { Buffy } \\
\text { coat }\end{array}$ & Plasma & $\begin{array}{c}\mu \mathrm{g} . / 10^{9} \\
\text { platelets } \dagger\end{array}$ \\
\hline & & & & \multicolumn{2}{|c|}{$\mu g . / m l}$. & $\begin{array}{l}\text { thousands/ } \\
\text { cu. } \mathrm{mm} \text {. }\end{array}$ & \multicolumn{2}{|c|}{$\begin{array}{l}\mu \mathrm{g} . / \mathrm{ml} \text {. of whole } \\
\text { blood }\end{array}$} & \\
\hline $\begin{array}{r}1 \\
2 \\
3 \\
4 \\
5 \\
6 \\
7 \\
8 \\
9 \\
10 \\
11\end{array}$ & $\begin{array}{l}M \\
M \\
F \\
M \\
M \\
M \\
F \\
M \\
M \\
F \\
F\end{array}$ & $\begin{array}{l}49 \\
37 \\
18 \\
91 \\
41 \\
48 \\
36 \\
28 \\
66 \\
63\end{array}$ & $\begin{array}{r}56 \\
296 \\
118 \\
817 \\
191 \\
429 \\
469 \\
69 \\
351 \\
257\end{array}$ & $\begin{array}{l}0.060 \\
0.064 \\
0.025 \\
0.130 \\
0.060 \\
0.060 \\
0.048 \\
0.025 \\
0.075 \\
0.080\end{array}$ & $\begin{array}{l}<0.010 \\
<0.015 \\
<0.008 \\
<0.005 \\
<0.005\end{array}$ & $\begin{array}{r}171 \\
212 \\
95 \\
349 \\
290 \\
435 \\
195 \\
160 \\
185 \\
258 \\
207\end{array}$ & $\begin{array}{c}0 \\
0.003 \\
0 \\
0 \\
0.027 \\
0.009 \\
0.015 \\
0.013 \\
0.019 \\
0.014\end{array}$ & $\begin{array}{c}0 \\
0 \\
0 \\
0 \\
0 \\
0 \\
\\
0.007 \\
0.014 \\
0\end{array}$ & $\begin{array}{c}0 \\
0.027 \\
0 \\
0 \\
0.060 \\
0.046 \\
0.094 \\
0.016 \\
0.129 \\
0.067\end{array}$ \\
\hline & & $\begin{array}{l}47.7 \\
21.1\end{array}$ & $\begin{array}{l}305.3 \\
229.6\end{array}$ & $\begin{array}{l}0.063 \\
0.030\end{array}$ & & $\begin{array}{l}233 \\
95.5\end{array}$ & $\begin{array}{l}0.012 \\
0.012\end{array}$ & & $\begin{array}{l}0.053 \\
0.047\end{array}$ \\
\hline
\end{tabular}

* Blood obtained from the umbilical vein at birth.

t In the last column, the HT content of the unwashed platelets (the "buffy coat" of the platelet-rich plasma) is added to the HT content of the plasma, and the total related to the platelet count made on whole blood.

uterus of the rat, and was repeated in the presence of the $\mathrm{HT}$ inhibitor lysergic acid diethylamide $\left(10^{-7} \mathrm{Gm}\right.$. per ml.). The HT content of each sample of blood was related to the volume of the sample and to the number of platelets. Since the HT in blood is derived solely from the platelets, the latter mode of expression is considered the more informative. Platelets were counted in whole blood by Lempert's method (17). Parallel counts on whole blood, and on separated platelet-rich plasma, when corrected for the difference in volume, consistently gave values within 10 per cent of one another, whereas counts on washed suspensions of platelets were always slightly lower. We therefore felt justified, in this comparative study, in relating the total HT from unwashed platelets and plasma to the numbers of platelets in whole blood, thus avoiding delay in starting the extractions.

\section{RESULTS}

\section{Histamine}

The mean content of histamine of 10 samples of umbilical venous blood was $0.063 \pm 0.030^{1} \mu \mathrm{g}$. per $\mathrm{ml}$. (range, 0.025 to $0.130 \mu \mathrm{g}$. per $\mathrm{ml}$.). The mean basophil count was $47.7 \pm 21.1$ per $\mathrm{cu}$. $\mathrm{mm}$. (range, 18 to 91 basophils per cu. mm.), and the mean eosinophil count was $305.3 \pm 229.6$ per cu. $\mathrm{mm}$. (range, 56 to 817 eosinophils per cu. mm.). In the six samples of plasma which were examined, no activity due to histamine was detected; the values are recorded as less than the smallest amount which could be measured by the method

\footnotetext{
1 Standard deviation.
}

used, and this varied because of the varying sensitivity of different strips of guinea pig ileum (Table I).

In 15 healthy children, the mean value for the histamine content of whole blood was $0.049 \pm$ $0.020 \mu \mathrm{g}$. per ml. (range, 0.020 to $0.080 \mu \mathrm{g}$. per $\mathrm{ml}$.), the mean basophil count was $45.1 \pm 20.8$ per cu. mm. (range, 16 to 77 basophils per cu. mm.), and the mean eosinophil count was $256.2 \pm 196.7$ per cu. mm. (range, 47 to 664 eosinophils per cu. mm.). No histamine was detected in 12 of the 14 samples of plasma which were tested, but in two, very small amounts were found (Table II).

Figure 1 illustrates the relationship between the amount of histamine and the numbers of basophils and eosinophils in the 25 samples of blood.

The results obtained in the children with eosinophilia are shown in Table III. In Case 1, the initial eosinophil count and blood histamine level were abnormally high, and were still above normal 24 hours after starting cortisone (100 mg. daily by mouth). Both diminished rapidly when the dose of cortisone was increased to $200 \mathrm{mg}$. daily; the basophils increased slightly at first but one week later had almost disappeared, while at the same time the eosinophils had started to return. When the cortisone was stopped, the eosinophils and blood histamine again rose to abnormally high levels. In Case 2, the blood histamine fell in four 
TABLE II

Histamine and 5-hydroxytryptamine in the blood of healthy children

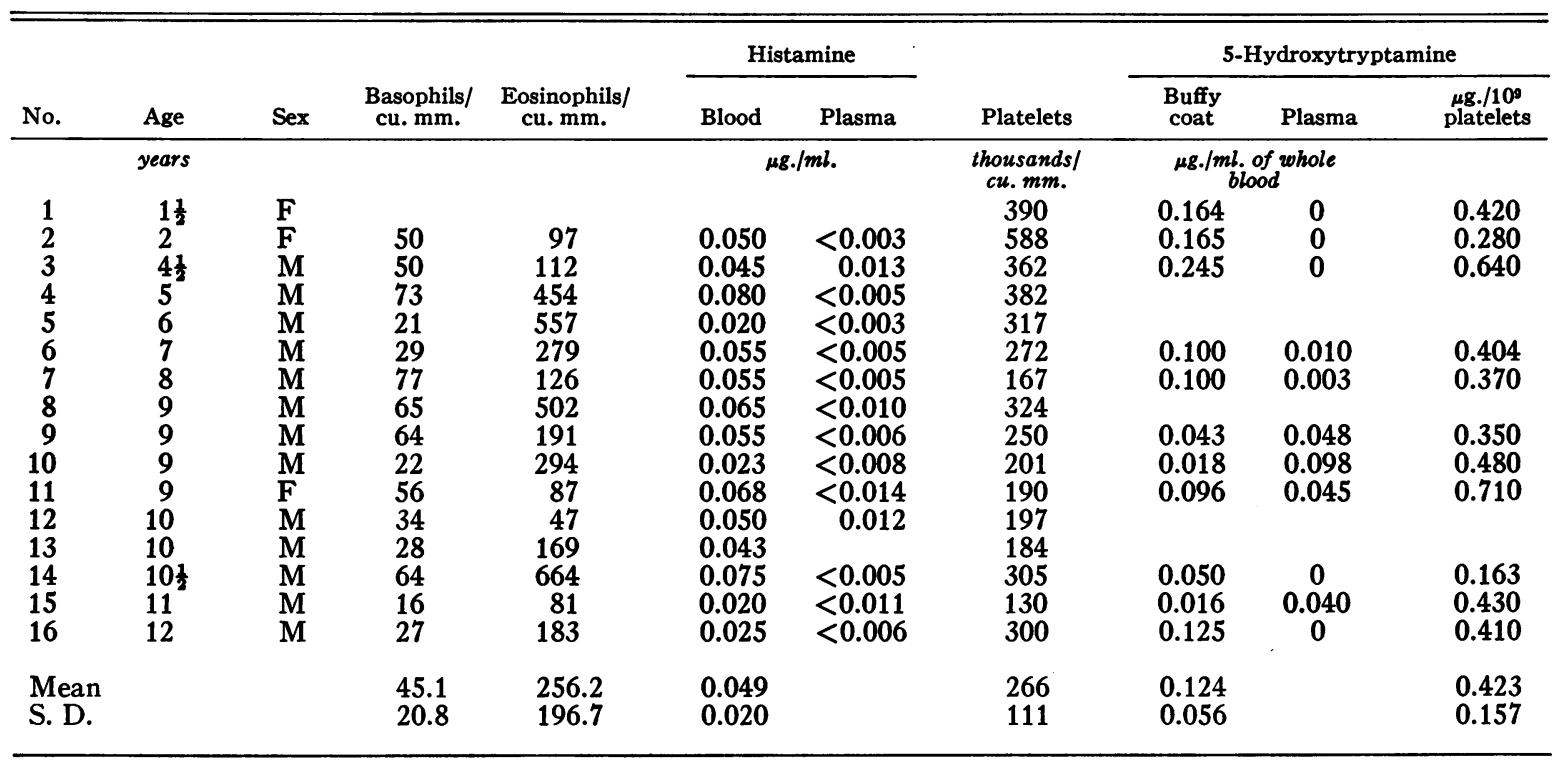

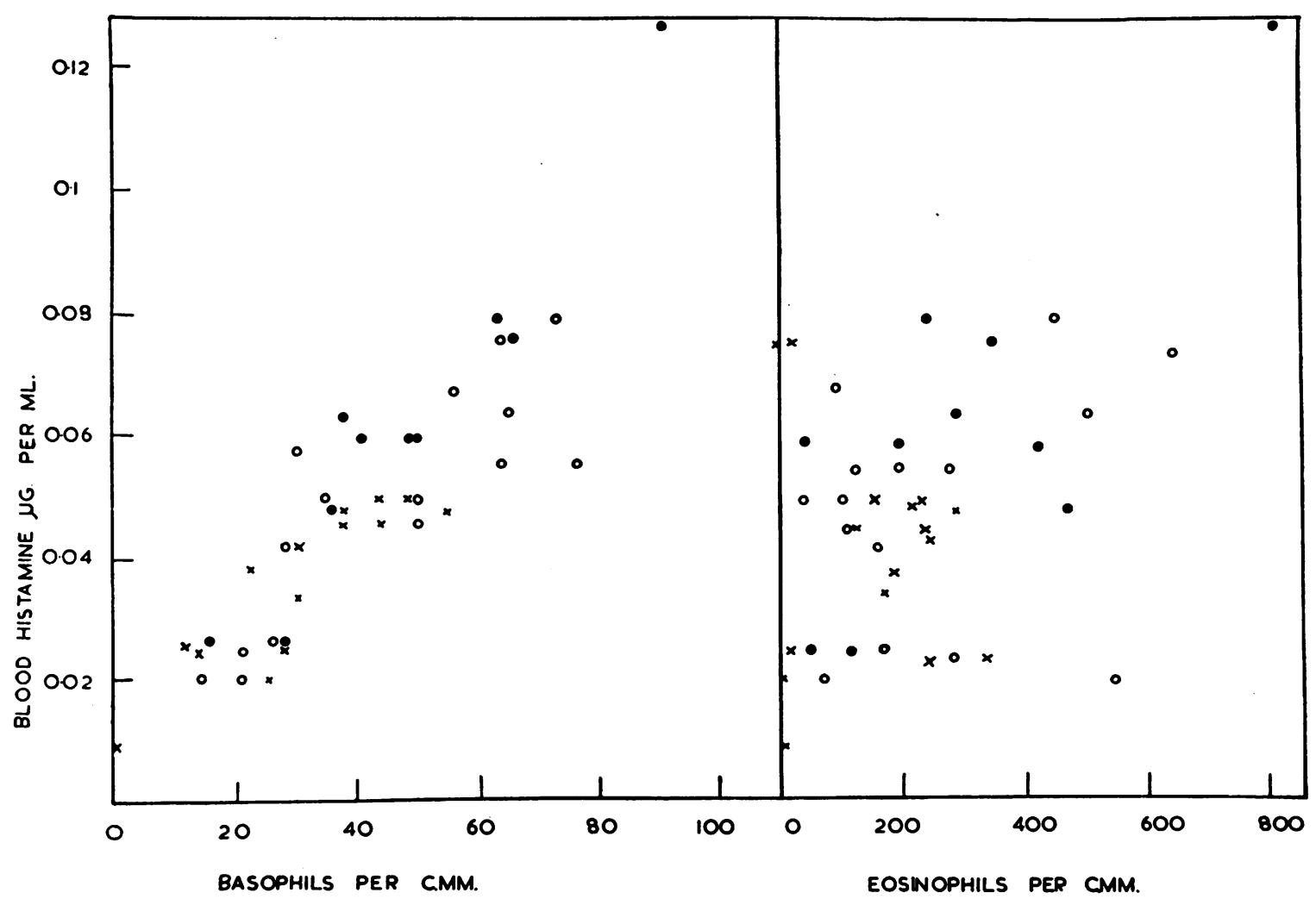

Fig. 1. Relationship Between the Amount of Histamine and the Numbers of Basophils (Left Panes) and the Numbers of Eosinophils (Right Panez) in tHe Blood of Infants and Children

Closed circles represent newborn infants; open circles, healthy children; crosses, children with acute rheumatism (Cases 5 and 6). 
TABLE III

Histamine and 5-hydroxytryptamine in the blood of children with eosinophilia (Cases 1 to 4) and with acute rheumatism (Cases 5 and 6 )

\begin{tabular}{|c|c|c|c|c|c|c|c|c|}
\hline \multirow[b]{2}{*}{ Case } & \multirow[b]{2}{*}{ Date } & \multirow{2}{*}{$\begin{array}{l}\text { Total } \\
\text { leuko- } \\
\text { cytes }\end{array}$} & \multirow{2}{*}{$\begin{array}{l}\text { Basophils/ } \\
\text { cu. mm. }\end{array}$} & \multirow{2}{*}{$\begin{array}{l}\text { Eosinophils/ } \\
\text { cu. mm. }\end{array}$} & \multicolumn{2}{|c|}{ Histamine } & \multirow{2}{*}{$\begin{array}{l}\text { 5-Hydroxy- } \\
\text { tryptamine }\end{array}$} & \multirow{2}{*}{$\begin{array}{l}\text { Oral } \\
\text { cortisone } \\
\text { acetate }\end{array}$} \\
\hline & & & & & Blood & Plasma & & \\
\hline & & $\begin{array}{l}\text { thousands/ } \\
c u . \mathrm{mm} \text {. }\end{array}$ & & & \multicolumn{2}{|c|}{$\mu g . / m l}$. & $\begin{array}{c}\mu g . / 10^{\circ} \\
\text { platelets }\end{array}$ & \\
\hline 1 & $\begin{array}{r}1 / 10 / 57 \\
1 / 22 / 57 \\
1 / 24 / 57 \\
1 / 28 / 57 \\
2 / 4 / 57 \\
2 / 28 / 57\end{array}$ & $\begin{array}{l}13.4 \\
13.3 \\
16.7 \\
13.3 \\
13.1 \\
14.2\end{array}$ & $\begin{array}{r}66 \\
44 \\
78 \\
81 \\
6 \\
41\end{array}$ & $\begin{array}{r}3,769 \\
4,144 \\
2,991 \\
174 \\
538 \\
1,489\end{array}$ & $\begin{array}{l}0.129 \\
0.146 \\
0.182 \\
0.080 \\
0.055 \\
0.114\end{array}$ & $\begin{array}{l}<0.005 \\
<0.005\end{array}$ & $\begin{array}{l}0.338 \\
0.127 \\
0.136 \\
0.142 \\
0.250\end{array}$ & $\begin{array}{c}\text { nil } \\
\text { nil } \\
100 \mathrm{mg} . \text { daily } \\
200 \mathrm{mg} \text {. daily } \\
200 \mathrm{mg.} \text { daily } \\
\text { nil }\end{array}$ \\
\hline 2 & $\begin{array}{r}3 / 8 / 57 \\
3 / 12 / 57 \\
4 / 18 / 57\end{array}$ & $\begin{array}{l}8.8 \\
7.9 \\
8.2\end{array}$ & $\begin{array}{l}59 \\
63 \\
35\end{array}$ & $\begin{array}{r}1,412 \\
760 \\
691\end{array}$ & $\begin{array}{l}0.346 \\
0.110 \\
0.041\end{array}$ & $<0.005$ & $\begin{array}{l}0.090 \\
0.390 \\
0.060\end{array}$ & $\begin{array}{l}\text { nil } \\
\text { nil } \\
\text { nil }\end{array}$ \\
\hline 3 & $\begin{array}{r}6 / 4 / 58 \\
7 / 2 / 58 \\
7 / 30 / 58 \\
8 / 20 / 58\end{array}$ & $\begin{array}{r}10.4 \\
8.3 \\
19.4 \\
13.2\end{array}$ & $\begin{array}{l}153 \\
141 \\
332 \\
264\end{array}$ & $\begin{array}{r}2,335 \\
3,627 \\
10,260 \\
8,260\end{array}$ & $\begin{array}{l}0.233 \\
0.133 \\
0.450 \\
0.311\end{array}$ & $\begin{array}{l}<0.007 \\
<0.003 \\
<0.009\end{array}$ & $\begin{array}{l}0.340 \\
0.194\end{array}$ & $\begin{array}{c}\text { nil } \\
\text { nil } \\
\text { nil } \\
200 \text { mg. } 6 \text { hours } \\
\text { previously }\end{array}$ \\
\hline 4 & $8 / 11 / 58$ & 11.2 & 113 & 2,310 & 0.133 & $<0.010$ & 0.075 & nil \\
\hline 5 & $\begin{array}{r}5 / 31 / 57 \\
6 / 3 / 57\end{array}$ & $\begin{array}{r}9.3 \\
16.2\end{array}$ & $\begin{array}{r}110 \\
25\end{array}$ & $\begin{array}{r}17 \\
2\end{array}$ & $\begin{array}{l}0.075 \\
0.020\end{array}$ & $<0.010$ & & 200 mg. daily \\
\hline 6 & $\begin{array}{r}11 / 19 / 56 \\
11 / 29 / 56 \\
12 / 12 / 56 \\
12 / 20 / 56 \\
1 / 11 / 57 \\
1 / 28 / 57 \\
2 / 15 / 57 \\
2 / 26 / 57 \\
3 / 18 / 57 \\
4 / 15 / 57 \\
5 / 16 / 57 \\
12 / 4 / 57 \\
8 / 21 / 58\end{array}$ & $\begin{array}{r}9.1 \\
8.4 \\
7.2 \\
10.9 \\
6.4 \\
11.0 \\
6.8 \\
5.9 \\
5.9 \\
8.2 \\
7.7 \\
6.2 \\
7.5\end{array}$ & $\begin{array}{r}16 \\
55 \\
28 \\
0 \\
13 \\
37 \\
48 \\
30 \\
23 \\
30 \\
44 \\
38 \\
44\end{array}$ & $\begin{array}{r}351 \\
295 \\
246 \\
0 \\
31 \\
128 \\
244 \\
170 \\
191 \\
250 \\
247 \\
224 \\
153\end{array}$ & $\begin{array}{l}0.023 \\
0.048 \\
0.023 \\
0.009 \\
0.025 \\
0.045 \\
0.050 \\
0.033 \\
0.038 \\
0.043 \\
0.045 \\
0.048 \\
0.050\end{array}$ & $<0.005$ & $\begin{array}{l}0.368 \\
0.253 \\
0.367 \\
0.272 \\
0.064 \\
0.130 \\
0.025 \\
0.080 \\
0.061 \\
0.114 \\
0.127 \\
0.178 \\
0.129\end{array}$ & $\begin{array}{c}\text { nil } \\
\text { nil } \\
\text { nil } \\
200 \text { mg. daily } \\
75 \text { mg. daily } \\
50 \text { mg. daily } \\
25 \text { mg. daily } \\
\text { nil } \\
\text { nil } \\
\text { nil } \\
\text { nil } \\
\text { nil } \\
\text { nil }\end{array}$ \\
\hline
\end{tabular}

days from its initial very high level to just above normal, coincidentally with a fall in the number of eosinophils, while the basophil count remained unchanged. Five weeks later, the basophil count had fallen from 63 to 35 per cu. mm., and the histamine was within normal limits. In Cases 3 and 4, the histamine levels and the basophil and eosinophil counts were abnormally high at every examination. In none of the four cases was histamine detected in the plasma.

Table III also records the results in Cases 5 and 6. In Case 5, eosinophils were virtually absent from the blood on both occasions and the level of blood histamine therefore reflects the basophil count almost directly, since no histamine was found in the plasma. The values obtained in Case 6 show the same relationships as are found in health (Figure 1).

\section{5-Hydroxytryptamine}

Ten samples of blood from the umbilical vein were tested for $\mathrm{HT}$; the mean content was $0.012 \pm$ $0.012 \mu \mathrm{g}$. per ml. Three of the 10 samples contained no measurable $\mathrm{HT}$ and the highest value recorded was $0.027 \mu \mathrm{g}$. per $\mathrm{ml}$. Expressed in terms of the platelet count, the mean content was $0.053 \pm 0.047 \mu \mathrm{g}$. per $10^{9}$ platelets, with a range from 0 to $0.129 \mu \mathrm{g}$. per $10^{9}$ platelets (Table I).

$\mathrm{HT}$ was measured in the blood of 11 healthy children (Table II). The mean content was $0.124 \pm 0.056 \mu \mathrm{g}$. per $\mathrm{ml}$. (range, 0.016 to 0.245 $\mu \mathrm{g}$. per ml.) or $0.423 \pm 0.157 \mu \mathrm{g}$. per $10^{9}$ platelets (range, 0.163 to $0.71 \mu \mathrm{g}$. per $10^{9}$ platelets). The HT content of the blood was thus significantly lower at birth than in later childhood ( $p<0.001)$.

The mean value obtained in the eight infants 
TABLE IV

5-Hydroxytryptamine in the blood of healthy infants

\begin{tabular}{|c|c|c|c|c|c|c|}
\hline \multirow[b]{2}{*}{ No. } & \multirow[b]{2}{*}{$\begin{array}{l}\text { Age in } \\
\text { weeks }\end{array}$} & \multirow[b]{2}{*}{ Sex } & \multirow[b]{2}{*}{ Platelets } & \multicolumn{3}{|c|}{ 5-Hydroxytryptamine } \\
\hline & & & & $\begin{array}{l}\text { Buffy } \\
\text { coat }\end{array}$ & Plasma & $\begin{array}{c}\mu \mathrm{gg} . / 10^{\circ} \\
\text { platelets }\end{array}$ \\
\hline & & & $\begin{array}{l}\text { thousands/ } \\
\text { cu. mm. }\end{array}$ & \multicolumn{2}{|c|}{$\begin{array}{c}\mu \mathrm{g} . / m_{\text {blood }} \text { of whole } \\
\text { bloo }\end{array}$} & \\
\hline $\begin{array}{l}1 \\
2 \\
3 \\
4 \\
5 \\
6 \\
7 \\
8\end{array}$ & $\begin{array}{r}7 \\
7 \\
10 \\
13 \\
15 \\
19 \\
20 \\
29\end{array}$ & $\begin{array}{l}F \\
F \\
F \\
F \\
M \\
F \\
F \\
F\end{array}$ & $\begin{array}{l}309 \\
574 \\
316 \\
430 \\
512 \\
359 \\
490 \\
551\end{array}$ & $\begin{array}{l}0.014 \\
0.050 \\
0.030 \\
0.048 \\
0.350 \\
0.019 \\
0.163 \\
0.070\end{array}$ & $\begin{array}{c}0 \\
0 \\
0 \\
0 \\
0 \\
0 \\
0 \\
0.04\end{array}$ & $\begin{array}{l}0.110 \\
0.087 \\
0.096 \\
0.110 \\
0.675 \\
0.053 \\
0.330 \\
0.200\end{array}$ \\
\hline \multicolumn{2}{|c|}{$\begin{array}{l}\text { Mean } \\
\text { S. D. }\end{array}$} & & $\begin{array}{l}442 \\
105\end{array}$ & $\begin{array}{l}0.098 \\
0.114\end{array}$ & & $\begin{array}{l}0.197 \\
0.212\end{array}$ \\
\hline
\end{tabular}

(Table IV) was $0.098 \pm 0.114 \mu \mathrm{g}$. per ml. (range, 0.014 to $0.35 \mu \mathrm{g}$. per ml.), or $0.197 \pm 0.212 \mu \mathrm{g}$. per $10^{\circ}$ platelets (range, 0.053 to $0.675 \mu \mathrm{g}$. per $10^{\circ}$ platelets). The data suggest that an increase in the HT content of the blood occurs rather abruptly at about 16 to 20 weeks of age (Figure 2).

Appreciable amounts of $\mathrm{HT}$ were found in the plasma of only seven of the 29 samples, and were attributed to faulty technique, the total blood level (i.e., the content of platelets and plasma) being within normal limits. In about half of the samples, the plasma contained another substance which caused contraction of the uterus, but this was unaffected by lysergic acid diethylamide, and may have been substance $P$. It was noted that this substance occurred more often in plasma obtained after a meal.

The results obtained in the children with eosinophilia are shown in Table III. The values are very variable, about half being below the lowest value found in the healthy children, and none being abnormally high. Some, but not all, of the low values obtained may have been due to the administration of cortisone. In Case 2, the second value $\left(0.39 \mu \mathrm{g}\right.$. per $10^{\circ}$ platelets $)$ was much higher than the first and third (0.09 and $0.06 \mu \mathrm{g}$. per $10^{\circ}$ platelets, respectively). The total amount of HT in the blood at the second estimation was $0.094 \mu \mathrm{g}$. per $\mathrm{ml}$, and since $0.09 \mu \mathrm{g}$. of this was in the plasma, it may have represented a truly abnormal plasma level, possibly associated with the allergic condition of the child.

The values obtained from the child with acute rheumatism (Case 6) are also shown in Table III.
The HT content of the blood was within the normal range until treatment with cortisone was started when it fell to very low levels. After cortisone was stopped, the HT increased slightly but never regained pretreatment levels.

In the incubation experiments, the platelets from the first newborn infant took up no $\mathrm{HT}$ at all, while those from the second, which initially had a total content of $0.01 \mu \mathrm{g}$., contained only $0.0375 \mu \mathrm{g}$. after incubation. In both the adults, the platelets increased their content nearly sevenfold during incubation.

\section{DISCUSSION}

\section{Histamine}

With increasing refinements of technique, successive workers have found less and less histamine in plasma, and the recent work of Adam, Hardwick and Spencer (5) indicates that human plasma normally contains less than 1 nanogram $(0.001$ $\mu \mathrm{g}$.$) per \mathrm{ml}$. Our method is not adequate for the precise measurement of such amounts, but it would detect an abnormal increase in the plasma histamine. In none of six samples of cord blood plasma was any histamine found and we cannot therefore

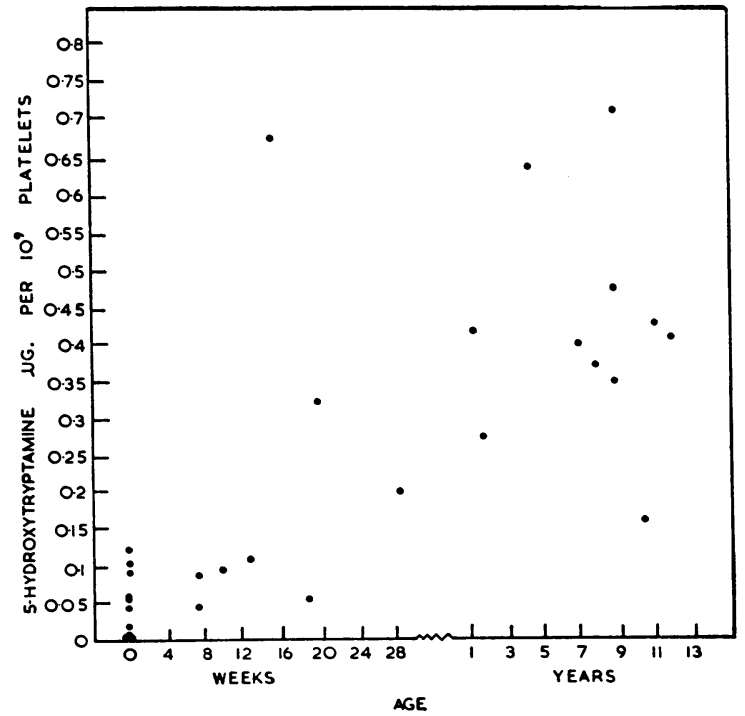

Fig. 2. Relationship Between the Amount of 5-HydROXYTRYPTAMINE IN THE BLOOD OF INFANTS AND Children and Their Age in Weeks or Years After BIRTH

The increase in the amount of 5-hydroxytryptamine with increasing age is statistically significant $(p<0.01)$. 
confirm Pettay's finding of high levels of histamine in the plasma at birth (6). Such high levels may have been due to his method of collecting the blood directly from the placental end of the divided cord.

All except one of the values obtained for the histamine content of cord blood fell within the normal adult range. The one exception $(0.130 \mu \mathrm{g}$. per ml.) was associated with very high counts of basophils and eosinophils. The mean value $(0.063$ $\mu$ g. per ml.) was significantly higher $(p<0.001)$ than the mean of $0.040 \mu \mathrm{g}$. per ml. found previously in healthy adults (1) but did not differ significantly $(p>0.1)$ from the mean value of 0.049 $\mu \mathrm{g}$. per ml. found in the 15 healthy children in this study.

The mean numbers of basophils and eosinophils were rather higher than those recorded previously in umbilical venous blood (15) but the difference is only statistically significant in respect of the eosinophils $(p<0.05)$ and the number of these cells in the blood at birth is known to be extremely variable (18). Figure 1 shows the close relationship between basophils and histamine in the 10 samples.

We conclude that the blood in the umbilical vein does not differ fundamentally from adult blood in respect to the distribution of histamine among the various elements of the blood, and that the tendency to higher levels simply reflects differences in the numbers of circulating basophils and eosinophils.

All the values for blood histamine in the 15 healthy children fell within the normal adult range and the mean value of $0.049 \mu \mathrm{g}$. per ml. did not differ significantly $(p>0.05)$ from the mean value of $0.040 \mu \mathrm{g}$. per ml. found in adults. Our results are similar to those of Maas, Fehmers and Strengers (4) who estimated the blood histamine in 51 normal children; the mean value calculated from their data was also $0.049 \mu \mathrm{g}$. per $\mathrm{ml}$.

The basophil and eosinophil counts in the 15 children all fell within the normal range and the mean counts did not differ significantly from those found in 67 other healthy children (16). Figure 1 indicates that there is a close relationship between the number of basophils and the histamine content of the blood.

Histamine was found in the plasma of only two of the children and the small amounts present were probably due to liberation of histamine from cells into the plasma at the time of collection rather than to true increases in the plasma level. Thus our results indicate that there is no difference between children and adults in the amount and distribution of histamine in the blood.

In general, when the basophil count is high the eosinophil count is likely to be high, and when basophils are scanty, eosinophils are also few in number. Many exceptions to this generalization occur, however, and in a study of 82 adults, Boseila and Uhrbrand (19) found that the correlation between the numbers of basophils and eosinophils was not statistically significant. Nevertheless, in many hundreds of counts we have seldom found a numerical disparity sufficiently great to be of value in defining the role of each type of cell in the carriage of histamine. The observations on the patients with eosinophilia are therefore particularly valuable, since the abnormally high levels of histamine in the presence of normal basophil counts indicate that the eosinophils contained large amounts of the amine. It might be suggested that the basophils were assuming a much greater load than usual, although there is evidence that the histamine content of basophils does not vary much (3). The observations in Case 1, however, show clearly that the eosinophils may at times contain substantial quantities of histamine. Thus, when basophils were virtually absent from the blood on February 4th, the histamine content was $0.055 \mu \mathrm{g}$. per $\mathrm{ml}$., and since none of this was in the plasma, it must have been in the eosinophils, which were present in relatively large numbers ( 538 per cu. mm.). This does not mean, of course, that the eosinophils always contain histamine, and in fact there is ample evidence that they do not. All our children with eosinophilia had abnormally large amounts of histamine in the blood, but this is by no means always the case (20), and the varying quantities found by other workers indicate that the histamine content of the eosinophils may fluctuate greatly, even allowing for possible variations in the numbers of basophils.

The data obtained in Case 5 indicate just as clearly that the basophils contained histamine, since in the presence of large numbers of basophils and in the virtual absence of eosinophils, there was a considerable amount of histamine 
TABLE V

5-Hydroxytryptamine in the blood of healthy adults

\begin{tabular}{|c|c|c|c|c|c|}
\hline \multirow[b]{2}{*}{ No. } & \multirow[b]{2}{*}{ Sex } & \multirow[b]{2}{*}{ Platelets } & \multicolumn{3}{|c|}{ 5-Hydroxytryptamine } \\
\hline & & & $\begin{array}{l}\text { Buffy } \\
\text { coat }\end{array}$ & Plasma & $\begin{array}{c}\mu \mathrm{\mu g} . / 10^{9} \\
\text { platelets }\end{array}$ \\
\hline & & $\begin{array}{l}\text { thousands/ } \\
\text { cu. mm. }\end{array}$ & \multicolumn{2}{|c|}{$\begin{array}{l}\mu \mathrm{g} . / \mathrm{ml} \text {. of whole } \\
\text { blood }\end{array}$} & \\
\hline $\begin{array}{l}1 \\
2 \\
3 \\
4 \\
5 \\
6\end{array}$ & $\begin{array}{l}M \\
M \\
F \\
M \\
M \\
M\end{array}$ & $\begin{array}{l}214 \\
180 \\
220 \\
180 \\
235 \\
356\end{array}$ & $\begin{array}{l}0.045 \\
0.083 \\
0.094 \\
0.027 \\
0.081 \\
0.092\end{array}$ & $\begin{array}{c}0.011 \\
0 \\
0 \\
0.021 \\
0 \\
0\end{array}$ & $\begin{array}{l}0.260 \\
0.460 \\
0.427 \\
0.150 \\
0.344 \\
0.260\end{array}$ \\
\hline $\begin{array}{l}\text { Mean } \\
\text { S. D. }\end{array}$ & & $\begin{array}{r}231 \\
65\end{array}$ & $\begin{array}{l}0.076 \\
0.022\end{array}$ & & $\begin{array}{l}0.317 \\
0.115\end{array}$ \\
\hline
\end{tabular}

which was not in the plasma and must therefore have been in the basophils. The close correlation between the basophils and the blood histamine level in the absence of eosinophils lends further support to the view that the histamine content of each basophil remains relatively constant. The high basophil count in Case 5 is unusual in the acute stage of rheumatism (16) but it may have been due to a poor response to stress in this severely ill child. Basophils are generally less responsive than eosinophils to the action of corticosteroids (3) and may even increase in number at first while the number of eosinophils is falling (21), an effect seen in Case 1 (Table III).

The basophil and eosinophil counts show characteristic changes in acute diseases of childhood (16) but the variations in blood histamine levels have not been studied. However, the data in Cases 5 and 6 do suggest that the same relationships between basophils, eosinophils and blood histamine pertain in acute disease as in health (Figure 1 and Table III). Much work has been carried out on the variations of blood histamine in allergic conditions, and recently it has been shown that some allergic children may have consistently elevated levels of histamine in the blood (4). Such work would be of greater value if the distribution of the histamine between the various blood elements were known. An increase in total blood histamine due to a high level in the plasma, such as occurs in experimental allergic reactions (22, 23), has a significance quite different from that of an increase due to a rise in the numbers of basophils or eosinophils. The latter may, of course, indicate disordered histamine metabolism, since the cells may be numerous because there are increased quantities of histamine to be transported, but equally the blood histamine may only be raised because the numbers of basophils and eosinophils have increased, which may be for some reason unconnected with histamine metabolism. It is evident that in assessing the significance of the amount of histamine in the blood, its distribution between cells and plasma must be taken into account.

\section{5-Hydroxytryptamine}

Our results indicate that the blood at birth contains little or no HT, that there is only a slight tendency to rise during the next four months, and that there is then rather a rapid rise to childhood levels, which are comparable with those which we have found in adults (Table V). The rise in the HT content of the blood does not depend on alterations in the platelet count, and is thus due to a real increase in the amount of $\mathrm{HT}$ per platelet.

There appear to be at least three possible explanations of the low levels observed at birth. First, the platelets might have been temporarily depleted of HT as a result of parturition, but this seems unlikely, since the rise in the level did not occur for several months after birth. Second, there might have been no HT for the platelets to take up. The apparent absence of 5-hydroxyindole acetic acid from human amniotic fluid (24) seems to support this hypothesis, since it suggests that no $\mathrm{HT}$ is being metabolized during fetal life, at least by the normal route. However, we have found that an extract from the terminal ileum of a stillborn fetus caused a contraction of the atropinized estrous uterus equivalent to $2.5 \mu \mathrm{g}$. per $\mathrm{Gm}$. of HT, which was abolished by lysergic acid diethylamide. This suggests that $\mathrm{HT}$ is present in the human body during intrauterine life, as has already been shown for other mammals (25).

The third, and in our opinion the most likely, explanation of the low levels of HT in cord blood is that the capacity of the platelets for taking up $\mathrm{HT}$ is poorly developed at birth. The results of our experiments would appear to support this view, since even after incubation with $H T$, the platelets of the newborn infants contained less than normal adult platelets.

Our studies afford no explanation for the in- 
crease in the platelet content of HT at about four months after birth. It seems unlikely to be related to a change in diet, for the introduction of cereal foods at this age does not greatly increase the intake of tryptophan, and we can only suggest that in some way the ability of the platelets to take up HT matures at about this time.

\section{Histamine and 5-hydroxytryptamine}

Although histamine and 5-hydroxytryptamine are closely associated in the cells of some species, such as the mast cells of the rat and the platelets of the rabbit, it appears that in man they are neither derived from the same source nor contained in the same cells. We were therefore surprised to find a significant $(p<0.01)$ inverse relationship between the total quantities of histamine and HT in the blood of the 10 healthy children in whom both substances were measured (Table II). This relationship did not depend on a negative correlation between the basophils and eosinophils and the platelets, and indeed, as far as we are aware, there is normally no numerical relationship between these cells. Under experimental conditions, HT does have an eosinopenic effect $(26,27)$ and may also liberate histamine (28), but the quantities required to produce these effects are much larger than those found in normal blood, where in any case the $\mathrm{HT}$ is within the platelets and therefore unlikely to exert any such action.

We cannot confirm this relationship from our other results, which are not comparable because of the difference noted in the uptake of HT by platelets in the newborn period and because any negative correlation would cease to exist on the administration of cortisone, which lowers the levels of both histamine and HT $(1,29)$. If there is indeed an inverse relationship between histamine and HT in human blood, we are unable to account for it.

\section{SUMMARY}

1. The amount of histamine in the blood is closely related to the number of circulating basophils at birth and throughout childhood, and there is little or no histamine in the plasma. Fresh evidence that both basophils and eosinophils contain histamine has been obtained from observations on children with eosinophilia and with acute rheumatism.

2. 5-Hydroxytryptamine in the blood in infancy and childhood is almost entirely contained in the platelets and little or none is present in the plasma. There is very little 5-hydroxytryptamine in the blood at birth but the amount increases rapidly at about the age of four months, and thereafter remains throughout childhood at levels comparable with those found in adult life.

3. The increase at four months is due to an increase in the amount of 5-hydroxytryptamine per platelet and not to an increase in the number of platelets. Experimental evidence suggests that the platelets contain only a small amount of 5-hydroxytryptamine at birth because their capacity for taking it up is poorly developed.

4. The values for 5-hydroxytryptamine in the blood of patients with eosinophilia were variable and observations on one patient indicated that abnormally large amounts might on occasion be present in the plasma.

5. An inverse relationship was found between the amounts of histamine and 5-hydroxytryptamine in the blood of healthy children. The physiological significance of this observation is not known.

\section{ACKNOWLEDGMENTS}

We wish to thank Professor J. L. Henderson and Dr. J. Thomson for permission to study patients under their care. We are grateful to Professor R. B. Hunter for his help and encouragement. Dr. H. Holgate of Messrs. Sandoz, Ltd., kindly supplied the lysergic acid diethylamide.

\section{REFERENCES}

1. Mitchell, R. G., Butt, H. R., and Code, C. F. Histamine metabolism in diseases of the liver. J. clin. Invest. 1954, 33, 1199.

2. Graham, H. T., Lowry, O. H., Wheelwright, F., Lenz, M. A., and Parish, H. H., Jr. Distribution of histamine among leukocytes and platelets. Blood $1955,10,467$.

3. Code, C. F., and Mitchell, R. G. Histamine, eosinophils and basophils in the blood. J. Physiol. (Lond.) 1957, 136, 449.

4. Maas, J. W., Fehmers, G. A., and Strengers, T. Some aspects of blood histamine in normal, allergic and tuberculous children. Acta allerg. (Kbh.) 1956, 10, 170.

5. Adam, H. M., Hardwick, D. C., and Spencer, K. E. V. A method of estimating histamine in plasma. Brit. J. Pharmacol. 1957, 12, 397. 
6. Pettay, O. Investigations into the histamine content of umbilical blood. Acta paediat. (Uppsala) 1950, 39, 283.

7. Code, C. F., Mitchell, R. G., and Kennedy, J. C. The effect of cortisone on the number of circulating basophils and eosinophils: Is there a relationship between these cells? Proc. Mayo Clin. 1954, 29, 200.

8. Hamerston, O., Elveback, L., Halberg, F., and Gully, R. J. Correlation of absolute basophil and eosinophil counts in blood from institutionalized human subjects. J. appl. Physiol. 1956, 9, 205.

9. Erspamer, V. Pharmacology of indolealkylamines. Pharmacol. Rev. 1954, 6, 425.

10. Pare, C. M. B., Sandler, M., and Stacey, R. S. 5-Hydroxytryptamine deficiency in phenylketonuria. Lancet 1957, 1, 551.

11. Code, C. F. The quantitative estimation of histamine in the blood. J. Physiol. (Lond.) 1937, 89, 257.

12. Barsoum, G. S., and Gaddum, J. H. The pharmacological estimation of adenosine and histamine in blood. J. Physiol. (Lond.) 1935, 85, 1.

13. Roberts, M., and Adam, H. M. New methods for the quantitative estimation of free and conjugated histamine in body fluids. Brit. J. Pharmacol. 1950, $5,526$.

14. Moore, J. E., III, and James, G. W., III. A simple direct method for absolute basophil leucocyte count. Proc. Soc. exp. Biol. (N. Y.) 1953, 82, 601.

15. Mitchell, R. G. Circulating basophilic leucocyte counts in the newborn. Arch. Dis. Childh. 1955, $30,130$.

16. Mitchell, R. G. Basophilic leucocytes in children in health and disease. Arch. Dis. Childh. 1958, 33, 193.

17. Lempert, $\mathbf{H}$. A modified technique for the enumeration of blood platelets. Lancet 1935, 1, 151.
18. Farquhar, J. W. Control of the blood sugar level in the neonatal period. Arch. Dis. Childh. 1954, 29, 519.

19. Boseila, A. A., and Uhrbrand, H. Basophil-eosinophil relationship in human blood. Acta endocr. (Kbh.) 1958, 28, 49.

20. Code, C. F. Histamine in blood. Physiol. Rev. 1952, $32,47$.

21. Noah, J. W., and Brand, A. The effect of corticosteroid administration upon blood histamine content. J. Allergy 1957, 28, 405.

22. Katz, G., and Cohen, S. Experimental evidence for histamine release in allergy. J. Amer. med. Ass. 1941, 117, 1782.

23. Noah, J. W., and Brand, A. Correlation of blood histamine release and skin test response to multiple antigens. J. Allergy 1955, 26, 385.

24. Erspamer, V. Observations on the fate of indolalkylamines in the organism. J. Physiol. (Lond.) 1955, 127, 118.

25. Faustini, R. The enteric distribution of 5-hydroxytryptamine (enteramine, serotonin) in some large domestic mammals and the appearance of $5 \mathrm{HT}$ and the enterochromaffin cell system in the embryonic calf. Amer. J. vet. Res. 1955, 16, 397.

26. Steiner, F. A., and Hedinger, C. Thrombozytose und Eosinopenie bei Ratten nach einmaliger 5-Oxytryptamininjektion. Experientia (Basel) 1956, 12, 109.

27. Milkovic, S., and Supek, Z. Uber die wirkung von 5-Oxytryptamin (Serotonin) und Lysergsäurediäthylamid (LSD) auf das Hypophysen-Nebennierenrinde-System. Naunyn-Schmiedeberg's Arch. exp. Path. Pharmak. 1956, 228, 146.

28. Feldberg, W., and Smith, A. N. Release of histamine by tryptamine and 5-hydroxytryptamine. Brit. J. Pharmacol. 1953, 8, 406.

29. Cass, R. Unpublished data.

\section{SPECIAL NOTICE TO SUBSCRIBERS}

Post Offices will no longer forward the Journal when you move.

Please notify The Journal of Clinical Investigation, Business

Office, 333 Cedar Street, New Haven 11, Conn., at once when you have a change of address, and do not omit the zone number if there is one. 